\title{
The Regulatory Framework Governing Traditional Arbitration in Resolving Islamic Banking Disputes in Malaysia: The Time for Change
}

\author{
Mohamad Fateh Labanieh¹, Mohammad Azam Hussain², Nazli Mahdzir³ \\ 1 School of Law, Universiti Utara Malaysia, Malaysia \\ fatih.labanie@gmail.com \\ 2 School of Law, Universiti Utara Malaysia, Malaysia \\ Legal \& Justice Research Center, School of Law, Universiti Utara Malaysia, Malaysia \\ hmazam@uum.edu.my \\ 3 School of Law, Universiti Utara Malaysia, Malaysia \\ mnazli@uum.edu.my
}

\begin{abstract}
Introduction to The Problem: Malaysia has established its place as a global leader in Islamic banking due to the considerable efforts made by the Malaysian lawmakers to enhance the Islamic banking dispute resolution framework and provide the Islamic banking disputants with several resolution mechanisms, such as traditional arbitration. However, using traditional arbitration in resolving Islamic banking disputes is not free from criticisms. Therefore, there is a need to find an alternative or enhanced form of traditional arbitration mechanism.

Purpose/Objective Study: This article examines the regulatory framework governing traditional arbitration in resolving Islamic banking disputes in Malaysia.

Design/Methodology/Approach: This article is based on doctrinal legal research Methodology. Primary data was secured from several sources, such as Acts, Laws, and Court Cases. While secondary data was collected from books, journal articles, and online databases. Both data are analyzed by using critical and analytical approaches. Findings: It is found that Arbitration Act 2005 (Act 646) and I-Arbitration Rules 2018 have been subjected to several amendments to align with the international norms and best practices. However, Malaysian lawmakers should start thinking out of the box by reinforcing the Islamic banking disputants with an effective resolution mechanism known as electronic arbitration (hereinafter referred to as "e-arbitration"). Doing so would facilitate prompt access to justice in Islamic banking disputes in Malaysia.
\end{abstract}

Paper Type: Research Article.

Keywords: Arbitration; E-Arbitration; Online Dispute Resolution (ODR); Islamic Banking

\section{Introduction}

In Islamic law, the concept of arbitration is referred to as tahkim (Khakimov, 2020). Indeed, tahkim is an old mechanism. It has been acknowledged by the four sources of Shariah, such as the Holy Quran, Sunnah (the body of Islamic custom and practice 


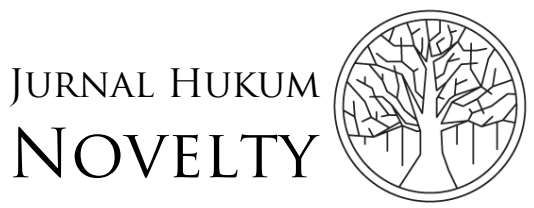

Volume 12, Issue 02, 2021, pp. 137-152

based on words, actions, or approvals of the Prophet Muhammad), Ijmä' (it means consensus, which is the acceptance of a matter by a specified group of people), and Qiyās (it means analogy, the principle of analogy applied in the interpretation of points of Islamic law not clearly covered in the Holy Quran or Sunnah: analogical inference or deduction), along with the primary four (4) Islamic Schools of Thoughts, such as Hanafi, Māliki, Syāfie, and Hanbali (Seyadi, 2019).

In the Holy Quran, there are three (3) verses that give approval and recognition to tahkim, among them:

"If you fear a breach between them twain (the man and his wife), appoint (two) arbitrators, one from his family and the other from her family; if they both wish for peace, Allah will cause their reconciliation. Indeed, Allah is Ever All-Knower, Well-Acquainted with all things (The Holy Quran: chapter 4 , verse 35 ).

Verily! Allah commands that you should render back the trusts to those to whom they are due; and that when you judge between men, you judge with justice. Verily, how excellent is the teaching which He (Allah) gives you! Truly, Allah is Ever All-Hearer, All-Seer (The Holy Quran: chapter 4, verse 58).

But no, by your Lord, they can have no faith, until they make you judge in all disputes between them, and find in themselves no resistance against your decisions, and accept (them) with full submission (The Holy Quran: chapter 4 , verse 65)."

From a Sunnah perspective, during the time of the Prophet Muhammad (Peace be Upon Him), he promoted and practiced tahkim, and sometimes acted as a hakam or muhakkam (the arbitrator) between tribes and individuals to resolve their disputes (Al-Shibli, 2018; Khoukaz, 2017; Link \& Haftel, 2019). For instance, when the Prophet Muhammad (Peace be Upon Him) was in Makkah, he was requested by the people of Medina to resolve a dispute between two (2) large Arab tribes of al-Aus and al-Khazraj with three (3) Jewish (Mahdi \& Hak, 2006).

Further, the Prophet Muhammad (Peace be Upon Him) encouraged the tribes to resolve their disputes through tahkimm (Arifin \& Mansar, 2019). Moreover, tahkimm is described as the spontaneous, and more or less improvised move by two or more parties in dispute to submit their case to a third party called a hakam or muhakkam (Allie, 2020). Based on the previous facts, it is evident that the emergence of the Islamic religion has given tahkim substantial support. It is because Islamic religion emphasizes the concept of harmony rather than hostilities and adopts the principle of compromise instead of confrontation (Dahlan, 2018).

In the context of this article, Malaysia has established its place as a global leader in Islamic banking (Husseini et al., 2019; Komijani \& Taghizadeh-Hesary, 2018). It is due to the considerable efforts made by the Malaysian lawmakers to enhance the Islamic banking dispute resolution framework, which includes litigation (court proceedings) and alternative dispute resolution (ADR) mechanisms, such as traditional arbitration, traditional mediation. 
Indeed, the disputing parties in Malaysia prefer to resolve their Islamic banking disputes through traditional arbitration that enables them to resolve their dispute through non-violent processes. Specifically, traditional arbitration is the most cooperative mechanism for resolving Islamic banking disputes whereby the disputing parties mutually agree to arbitrate their dispute by entering into an arbitral agreement. This would lead to a win-win situation and preserve the ongoing and underlying relationship between the Islamic banking clients and their Islamic banks, unlike litigation (court proceedings).

Furthermore, traditional arbitration is a confidential mechanism since all the traditional arbitral proceedings, such as oral hearings, are conducted privately and closed. Besides, traditional arbitration is seen as a fast, cheap, and flexible mechanism in resolving Islamic finance disputes (Maita, 2014), including Islamic banking disputes. The earlier unique features and advantages of traditional arbitration are reflected in the number of the traditional arbitration cases registered at the Asian International Arbitration Centre (hereinafter referred to as "AIAC"). For example, between August and November 2020, the AIAC registered fifty-two (52) and eight (8) domestic and international arbitration cases, respectively (Asian International Arbitration Centre, 2020).

Several efforts are made to define traditional arbitration. According to the linguistic viewpoint, the term traditional arbitration is originated from the Latin word "arbitrae", which means "the authority to cope with something with wisdom" (Al Hamed, 2016). From the academic perspective, the arbitration is "a process by which parties consensually submit a dispute to a non-governmental decision-maker, selected by or for the parties, to render a binding decision resolving a dispute in accordance with neutral, adjudicatory procedure affording the parties an opportunity to be heard" (Born, 2009; Fortese \& Hemmi, 2015; Strong, 2012).

Besides, it is worth noting that the traditional arbitration process falls into two types: ad hoc and institutional arbitration (Schroeter, 2018). Ad hoc arbitration is a proceeding in which the parties are obligated to design the arbitration processes. This includes selecting the arbitrators, the number of arbitrators, and the determination of the applicable laws (Rajoo, 2010; Shokrani, 2018). This type relies on the parties' cooperation, supported by potential recourse to national courts in case the parties do not agree on any of its aspects, such as the appointment of the arbitrator (Born, 2010).

On the other hand, institutional arbitration is a proceeding in which the parties in their arbitral agreement select an arbitration institution to administrate their arbitration. In this type, the arbitral institution does not resolve the parties' underlying substantive dispute or act as an arbitrator but instead administers the arbitral proceedings that are conducted and decided by the arbitral members (Born, 2010; Berger, 2018). 
In the context of this article, the emergence of information and communications technology (hereinafter referred to as "ICT") has paved the way for discovering a modern resolution mechanism known as e-arbitration. This mechanism is one of the online dispute resolution (ODR) mechanisms and has been significantly used because of its valuable advantages (Labanieh et al., 2021). Finally, it is essential to examine the underlying issues of development within the regulatory framework governing traditional arbitration in Malaysia and whether there is a need to find an alternative or enhanced form of traditional arbitration mechanism. This alternative or enhanced form should lead to a change in the mechanism for dispute resolution through earbitration that is entirely based on using electronic technologies.

\section{Methodology}

In the context of this article, doctrinal legal research is quite-fitted. This research design is helpful and necessary to examine the regulatory framework governing traditional arbitration in resolving Islamic banking disputes in Malaysia. The reason behind selecting this design is that doctrinal legal research is a "research in law" (Ali et al., 2017). It strives essentially to "discover, explain, examine, analyze and present in a systematic form the facts, principles, provisions, concepts, theories or the working of certain laws or legal institutions, in order to gain and present new knowledge and ideas or to suggest change and reform" (Yaqin, 2007). So, it contributes to the consistency, certainty, and continuity of the law and initiates further development of doctrines and legal principles. As a result, this design enables synthesis and harmony of the diverse viewpoints on the phenomenon of this study to provide results that guarantee permanent effect and value.

The primary legal source in doctrinal legal research covers the actual law in the form of Acts, court cases, constitutions, statutes, and administrative regulations and rules'. While the secondary data in doctrinal legal research covers anything that is more than the actual law. Therefore, since this article is based on doctrinal legal research, the primary data was sourced from several sources, such as Acts, Laws, and Court Cases. While secondary data was collected from books, journal articles, and online databases (Mohamed, 2016). Finally, both data had been systematically analyzed by using a critical and analytical approach.

\section{Results and Discussion}

The regulatory framework governing traditional arbitration in resolving Islamic banking disputes in Malaysia is divided into ad hoc arbitration and institutional arbitration. The following discusses the development of ad hoc arbitration and institutional arbitration in resolving Islamic banking disputes in Malaysia, respectively.

\section{The Development of the Ad Hoc Arbitration System in Resolving Islamic Banking Disputes in Malaysia}

In Malaysia, the ad hoc arbitration system passed through seven (7) phases of the 
amendment. The following discusses each phase separately.

\section{The First Phase}

The first phase started from the Arbitration Ordinance XIII of 1809 (hereinafter referred to as "the Ordinance of 1809") that was applied to the British-Indian controlled Straits Settlements, comprising of Malacca, Penang, and Singapore. It was the first statutory law on arbitration in Malaysia and came out due to several treaty arrangements between the British and Sultans of the Malay States (Idid \& Oseni, 2014; Rosli, 2021).

In 1890, the Ordinance of 1809 was replaced by Arbitration Ordinance 1890 in two Malay States, namely, Penang and Malacca. Moreover, in 1950, the Arbitration Ordinance 1890 was replaced by the Arbitration Ordinance 1950 that was based on the English Arbitration Act of 1889 and applied to all the States of the then Federation of Malaya. It was then approved as a wholesale adoption into the Arbitration Ordinance in 1952, and it is then known as the Arbitration Act 1952 (hereinafter referred to as "Act 1952") (Hua, 2018).

\section{The Second Phase}

The introduction of Act 1952 represented the second phase. Act 1952 was based on the United Kingdom Arbitration Act 1950. Although Act 1952 managed to serve as a clear and simple statute to govern traditional arbitration, by the end of the century, it became outdated and inadequate to resolve modern commercial disputes for several reasons. Firstly, it did not differentiate between international and domestic arbitration (Rajoo, 2009). Secondly, the Malaysian Courts under Act 1952 did not support traditional arbitration since they have comprehensive rights to interfere with traditional arbitral proceedings (Act 1952, sections 3; 5 (2); 6; 7; 9; 10 (3) 20 (1); 22; 23 ; 24 (2); 25; 26; 28).

\section{The Third Phase}

The third phase was embodied in introducing a new section "34" to Act 1952 in 1980. Section 34 (1) excluded the application of Act 1952 and any other written laws on two types of arbitrations, particularly those held under the International Centre for Settlement of Investment Disputes (ICSID) and the Kuala Lumpur Regional Centre for Arbitration (KLRCA). This means that the Malaysian Courts would not have the power to interfere in arbitration. Indeed, the application of section 34 was not based on the parties' acceptance, but rather it was based on the selection of arbitration rules provided for in the arbitral agreement (Rajoo, 2009). In this regard, section 34 did not follow the logical and normal divide between "international" and "domestic", but it followed the choice of arbitration regime in the arbitral agreement compared with the

\section{The Fourth Phase}

The fourth phase had appeared in the Convention on the Recognition and Enforcement of Foreign Arbitral Awards Act 1985 (Act 320) (hereinafter referred to as "Act 1985"). It was enacted to give effect to the New York Convention 1958 dealing 


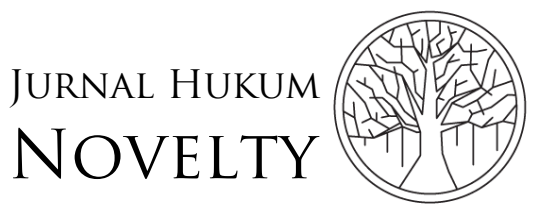

Volume 12, Issue 02, 2021, pp. 137-152

P-ISSN: 1412-6834

E-ISSN: 2550-0090

with the recognition and enforcement of international awards (Sections 38, 39 of the Arbitration Act 2005 (Act 646) replaced Act 1985).

\section{The Fifth Phase}

The fifth phase was emerged on $30^{\text {th }}$ December 2005 by introducing the Arbitration Act 2005 (Act 646) (hereinafter referred to as "Act 2005 (Act 646)") that was repealed Act 1952 and Act 1985 (Pradhan, 2018). Indeed, Act 2005 (Act 646) was based on the UNCITRAL Model Law on International Commercial Arbitration 1985 (hereinafter referred to as "MLICA 1985") and strongly influenced by the New Zealand Act 1996. Further, this Act distinguished between domestic and international arbitration and reduced the judicial intervention of the Malaysian High Court in traditional arbitration. Specifically, Act 2005 (Act 646) was divided into four (4) parts. Part I, II, and IV are mandatory and must be applied to domestic and international arbitration if Malaysia is the place of arbitration (Act 2005 (Act 646), sections 3 (2) (a); 3 (3) (a)). Besides, Act 2005 (Act 646) also provided for the opt-in/opt-out mechanism, by which the parties can modify their arbitration system. For instance, the parties to domestic arbitration can opt-out from the application of Part III of Act 2005 (Act 646) section 3 (2) (b)), and the parties to international arbitration can opt-in to the application of Part III of Act 2005 (Act 646) section 3 (3) (b)).

Furthermore, it contained many default sections that start with the sentence "unless otherwise agreed by the parties" and govern several issues relating to arbitral proceedings (Act 2005 (Act 646), sections 13 (1); 15 (1); 17 (2); 17 (3); 23; 26 (1); 28). The sentence "unless otherwise agreed by the parties" reflects the nonmandatory essence and gives more flexibility to the parties. Act 2005 (Act 646) sections 13 (2); 21 (1); 22 (1); 24 (1) also emphasized the parties' right to design their arbitral procedures by recognizing the principle of party autonomy.

Moreover, Act 2005 (Act 646) has recognized the principle of competencecompetence (Kompetenz-Kompetenz) that does not exist in Act 1952. For instance, section 18(1) provides that the arbitral tribunal may rule on its own jurisdiction. This includes any objections concerning the existence or validity of the arbitral agreement. In specific, under section 18 of Act 2005 (Act 646), the challenging party can raise two (2) types of pleas. Firstly, the arbitrator has no jurisdiction. Secondly, the arbitrator has exceeded the scope of his/her jurisdiction (Act 2005 (Act 646), sections 18 (3) to (6)). The arbitrator can decide on the issues mentioned above either in an award on the merits or as a preliminary question (Act 2005 (Act 646), section 18 (7)). It is worth noting that there are time limits to raise the above-mentioned issues by the interested party (Act 2005 (Act 646), sections 18 (3); (5)).

Further, section 18 (2) of Act 2005 (Act 646) acknowledged the separability principle. This means that the agreement to arbitrate came in a separate agreement or included in the main contract, which is deemed separate from the main contract (The 
Government of India v. Petrocon India Limited [2016] MLJU 233). This leads to two results; firstly, the arbitral agreement will not be null even if the main contract is invalid (Arul Balasingam v. Ampang Puteri Specialist Hospital Sdn Bhd [2012] 6 MLJ 104). Secondly, the arbitral agreement can be governed by a law that differs from the law applied to the main contract.

\section{The Sixth Phase}

The Malaysian traditional arbitration law came into its six (6) phase by the amendment made to an existing act via Arbitration Act (Amendment) 2011 (Act A1395) (hereinafter referred to as "Act 2011 (Act A1395)"). This amendment came into force on $1^{\text {st }}$ of July 2011 and aimed to ensure sustainable growth of traditional arbitration in Malaysia because it strived to overcome the legal gaps in Act 2005 (Act 646) (Act 2011 (Act A1395), sections 2; 8; 10; 11; 30; 38; 39; 42; 51).

For example, Act 2011 (Act A1395) has amended section 8 of Act 2005 (Act 646) in order to restrict the interventionist powers of the Malaysian Court. Section 8, in its new version, followed article 5 of MLICA 1985. It stipulated that "no court shall intervene in matters governed by this Act, except where so provided in this Act." This is not in line with the previous version that follows these words "unless otherwise provided, no court shall intervene in any of the matters governed by this Act." In view of this, one may argue that there is no substantial difference between the wordings of section 8 of Act 2005 (Act 646) and the wordings of section 8 of Act 2011 (Act A1395). However, section 8 , in its new version, eliminated the vague application of section 8 of Act 2005 (Act 646). In specific, before amending section 8 of Act 2005 (Act 646), the Malaysian High Court has the power to intervene if it finds some provisions justifying such intervention, whether in Act 2005 (Act 646) or outside Act 2005 (Act 646) (Rajoo \& Choy, 2018).

Further, section 10 was also amended by Act 2011 (Act A1395). This section removed the power of the court to stay arbitral proceedings if it is convinced and satisfied that there is no dispute between the parties with respect to the issues sought to be referred to arbitration (Rajoo, 2019). In its new version, the Malaysian High Court is bound to refer the parties to arbitration unless it finds that the arbitral agreement is void or null, incapable of being performed, or inoperative. This amendment is in line with article 8(1) of MLICA 1985.

Moreover, Act 2011 (Act A1395) added special sections that addressed the admiralty proceedings (Act 2011 (Act A1395), sections 10 (2A) to 10 (2C)). Besides, it introduced section 10(4). This section stated that the power of the High Court to order a stay of proceedings is applied to the international seated arbitration and Malaysian seated arbitration. Likewise, Act 2011 (Act A1395) amended section 39(1) (a) (ii) of Act 2005 (Act 646) (Pradhan, 2018).

Currently, the validity of the arbitral agreement (only if the parties do not determine the law applied to their arbitral agreement) can be challenged by reference to the laws 


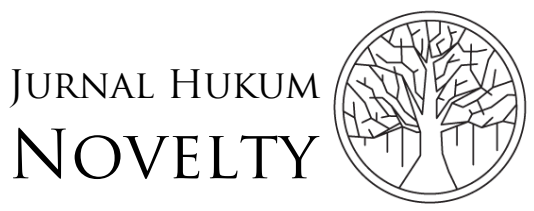

Volume 12, Issue 02, 2021, pp. 137-152

P-ISSN: 1412-6834

E-ISSN: 2550-0090

of the State where the award was made, unlike the previous version that enabled the interested party to challenge the arbitral agreement by reference to the law of Malaysia. It is important to note that section 39(1)(a)(ii), in its new version, conforms to article v(1)(a) of the New York Convention 1958.

Besides, Act 2011 (Act A1395) inserted a new subsection "1A" to section 42 of Act 2005 (Act 646). It provided the Malaysia High Court with the power to dismiss a question of law arising out of an arbitral award if it discovered that the question of law did not substantially affect the right of one or more of the parties (Act 2011 (Act A1395), section 42 (A1)). Although section 42 will not apply to international arbitration unless the parties agree otherwise in writing (Act 2005 (Act 646), section 3 (3) (b)), this section is against the Model Law's purpose that aims to limit the judicial intervention in the traditional arbitral proceedings (Rajoo \& Choy, 2018).

\section{The Seventh Phase}

Phase seven emerged in 2018. During this period, there were two rounds of amendments. The first round replaced the name of Kuala Lumpur Regional Centre for Arbitration (KLRCA) with Asian International Arbitration Centre (hereinafter referred to as "AIAC"). This would enable AIAC to take a wider international approach in offering its services. The second round focused on legislative reform. The first and second rounds (hereinafter referred to as "Act 2018") came into operation on 28 $8^{\text {th }}$ February and on $8^{\text {th }}$ May 2018, respectively (Rajoo, 2019). There is no doubt that Act 2018 played a vital role in developing Malaysian arbitration law and enhancing its attractiveness because it followed the UNCITRAL Model Law on International Commercial Arbitration 2006 (hereinafter referred to as "MLICA 1985 amended in 2006"), and the arbitral laws adopted by the leading countries in traditional arbitration (Asian International Arbitration Centre, 2018).

Indeed, Act 2018 introduced several amendments to Act 2005 (Act 646). For example, it included the emergency arbitrators in the definition of arbitral tribunal provided by section 2 of Act 2005 (Act 646). This amendment recognized the emergency arbitrators' decisions (Pradhan, 2018). Foreign lawyers are permitted to represent parties in traditional arbitration cases that are seated in Malaysia. According to the section 37A of the Legal Profession Act 1976 (Act 166), sections 36 and 37 (these sections do not permit non-Malaysian qualified lawyers to practice) of this Act should not apply to:

“(a) Any arbitrator lawfully acting in any arbitral proceedings; (b) any person representing any party in arbitral proceedings; or (c) any person giving advice, preparing documents and rendering any other assistance in relation to or arising out of arbitral proceedings except for court proceedings arising out of arbitral proceedings."

Moreover, Act 2018 added a new section "3A" to Act 2005 (Act 646). This section achieved three (3) purposes. Firstly, it enabled the parties to traditional arbitration to select any representative (not just a foreign or Malaysian lawyer) to advise and 
represent them in the arbitral proceedings. Secondly, it enhanced the principle of party autonomy in traditional arbitration. Thirdly, it allowed the parties seated in Sabah or Sarawak to be represented by West Malaysian legal practitioners or foreign legal practitioners (Rajoo, 2019). Act 2018 also amended section 4(1) of Act 2005 (Act 644). This section clarifies that any dispute can be resolved by traditional arbitration unless the arbitral agreement is against public policy or the subject matter of the dispute cannot be settled by traditional arbitration under the laws of Malaysia.

In addition, Act 2018 amended section 9(4) and brought new sections $9(4 \mathrm{~A})$ and (6) to Act 2005 (Act 646). After this amendment, the requirement of "in writing" was expanded to accommodate the arbitral agreement concluded orally, by conduct, or by other means, provided that its content is recorded in any form (Act 2018, section 9 (4) (a)). Also, the definition of "in writing" was expanded to include electronic communication (Act 2018, section 9 (4A)). Specifically, section $9(4 \mathrm{~A})$ gives the arbitral agreement concluded by using data message the same legal power as a traditional arbitral agreement. Moreover, Act 2018 amended sections 11 and 19 of Act 2005 (Act 646). It further added new sections from 19A to 19J. These sections established a system in respect of the requests for interim measures and provided useful guidance on operation, recognition and enforcement of interim measures. Act 2018 also amended section 30 of Act 2005 (Act 646). Presently, section 30 follows article 28 of MLICA 1985 amended in 2006. Besides, Act 2018 removed section 30(2) of Act 2005 (Act 646). This means that section 30 no longer distinguished between international and domestic arbitration regarding the law applied to the substance of the dispute. Currently, the arbitral tribunal should decide the dispute in accordance with the rules of law chosen by the parties to govern the substance of the dispute Act 2018, section 30 (1). This reform excluded the mandatory application of Malaysian law on domestic arbitration and supported the principle of party autonomy in traditional arbitration.

The enactment of Act 2018 also allowed the arbitral tribunal to issue a pre-award interest. Specifically, Act 2018 inserted a new subsection (6) to section 33 of Act 2005 (Act 646). Before adding this subsection, the arbitral tribunal can only issue postaward interest. Finally, it is worth noting that subsection (6) is not found in article 31 of MLICA 1985 as amended in 2006. Act 2018 also inserted new sections "41A and 41B" to Act 2005 (Act 646). In particular, section 41A of Act 2018 aimed to ensure confidentiality of the traditional arbitration. It stipulated that subject to certain exceptions, the parties to traditional arbitration are not allowed to disclose, communicate or publish any information relating to the arbitral proceedings or arbitral award made in those proceedings.

It is important to note that section 41A of Act 2018 was interpreted in the case of Dato' Seri Timor Shah Rafiq v. Nautilus Tug \& Towage Sdn Bhd [2019] 10 MLJ 693, where the Malaysian High Court refused the preliminary objection of the defendant on the ground that the prohibition, which is included in section $41 \mathrm{~A}$, should not apply 


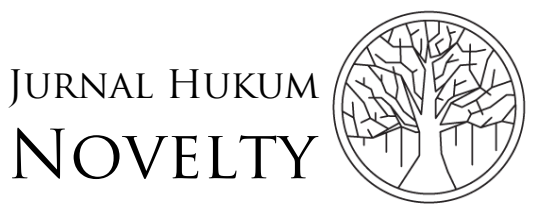

Volume 12, Issue 02, 2021, pp. 137-152

P-ISSN: $1412-6834$

E-ISSN: 2550-0090

to the non-parties to the traditional arbitration. In the same vein, section 41B of Act 2018 worked to enhance the confidentiality of the court-related arbitration proceedings. It stated that court proceedings under this Act could be heard privately unless a party applies to the court to conduct such proceedings in an open court or where the court is satisfied that those proceedings ought to be heard in an open court.

Finally, Act 2018 removed sections 42 and 43 from Act 2005 (Act 646). Previously, these sections should not apply to international arbitration unless the parties agree otherwise in writing (Act 2005 (Act 646), section 3 (3) (b)). In short, Act 2018 excluded the right of a party to refer to the Malaysian High Court on any questions of law arising from an award. However, the parties might apply to the Malaysian High Court to determine questions of law arising in the course of arbitration as provided under section 41 of Act 2005 (Act 646) (Rajoo, 2019). It is important to note that after removing sections 42 and 43 from Act 2005 (Act 646), there is no appeals procedure against the arbitral award made in Malaysia under Act 2005 (Act 646). However, the only recourse is to set aside such an award under section 37 .

\section{The Development of the Institutional Arbitration System in Resolving Islamic Banking Disputes in Malaysia}

When it comes to institutional arbitration in Malaysia, AIAC is the body that directly connects to traditional arbitration. This body was established in 1978 under the Asian-African Legal Consultative Organization (AALCO). It is a non-profit organization that provides institutional support as an independent and neutral venue for the conduct of international and domestic arbitration proceedings (Asian International Arbitration Center, 2021). In terms of Islamic banking, the AIAC (previously known as KLRCA) issued a set of rules, known as KLRCA Rules for Islamic Banking and Financial Services Arbitration 2007 (hereinafter referred to as "IBFSA Rules 2007"). The IBFSA Rules 2007 have been continuously updated. The current version is known as the I-Arbitration Rules 2018. These rules consist of three (3) parts: Part I is the I-Arbitration Rules, Part II is the UNCITRAL Arbitration Rules (as revised in 2013), and Part III is the Schedules. Further, if there is any conflict between Part I and Part II, the provisions in Part I shall supersede. Moreover, I-Arbitration Rules 2018 were acknowledged globally as the first rules that are mainly designed to resolve disputes arising from commercial contracts containing Shariah issues (Asian International Arbitration Center, 2021).

I-Arbitration Rules 2018 have several advantages. For instance, they include a rule (rule 11) that regulates the procedure for referral a Shariah matter included in an arbitration dispute to Shariah expert or Shariah Advisory Council (hereinafter referred to as "SAC"). They also contain a rule (rule 10) for the consolidation of proceedings and concurrent hearings. Further, they provide a self-contained system regarding emergency arbitrators (Asian International Arbitration Centre, 2021). It is vital to illustrate that I-Arbitration Rule 2018 is a delegated legislation (Mohamed et 
al., 2015) created by a body or person other than Parliament, unlike Act 2005 (Act 646) that is a statute enacted by the Parliament of Malaysia.

\section{Traditional Arbitration in the Digitial Era: The Time for Change}

Traditional arbitration becomes a significant mechanism of Islamic banking dispute resolution internationally and in Malaysia. This is due to the challenges facing litigation in resolving Islamic banking disputes. Specifically, the court system may destroy the underlying relationships between the Islamic banking clients and Islamic banks (Al-Shibli, 2017) because the court's judgment leads to a win-lose situation (Oseni \& Ahmad, 2012). In the same vein, Islamic banking disputants have to face the high cost of adjudication (Ali, et al., 2016). However, traditional arbitration is not much appealing as it used to be (Labanieh et al., 2019).

For this reason, there is a demand for a substantial change in traditional arbitration in accordance with the development of technology (Labanieh et al., 2020). Indeed, the arbitration industry in China, Thailand, Russia, and the United States of America (USA) has discovered a new mechanism know as e-arbitration, while others are working closely to automate the resolution process and integrate Artificial Intelligence (hereinafter referred to as "AI") with online dispute resolution (ODR), including e-arbitration (Bello, 2018). This is because AI helps the arbitrators in reviewing and analyzing the legal documents that the parties provide during the earbitral proceedings (Labanieh et al., 2021). At the domestic level, the Malaysian arbitration industry is still lagging behind, and it tends to be slow in catching up with these developments.

Hence, the following discusses one (1) e-arbitration service provider known as "UK eCourt" and provides a brief overview of the key advantages of e-arbitration. The UK eCourt is an ODR provider established in London. It can be used to resolve any kind of dispute or be employed as an advisory basis for those looking for a third-party opinion (Ecourt-The Online Justice System, 2021d). It provides two (2) main services (e-mediation and e-arbitration). Regarding e-arbitration, two main e-arbitration packages are offered in the UK eCourt, namely, standard package and premium package (Ecourt-The Online Justice System, 2021a).

The standard package includes four (4) basic steps. Firstly, select the number of words needed; secondly, submitting the case notes; thirdly, submitting payment; fourthly, UK eCourt returns a verdict. This package enables the parties to control the cost by pre-selecting the number of words needed for their case. Concerning the premium package, it is subjected to a six-step evaluation. Firstly, the party chooses his/her own Assessors or let UK eCourt does this task; secondly, selecting the number of words needed; thirdly, choosing a third party representative (if required); fourthly, submitting your case notes; fifty, submitting payment; sixthly, UK eCourt returns a Verdict (Ecourt-The Online Justice System, 2021a). This package provides the parties with more flexibility to select an 'assessor' and a representative. 


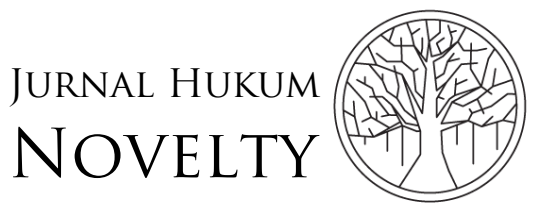

Volume 12, Issue 02, 2021, pp. 137-152

P-ISSN: 1412-6834

E-ISSN: 2550-0090

Furthermore, the fees are determined based on the number of words. The process of resolution takes seven (7) days in the simple arbitration case, while it takes twentyeight (28) days in the complex cases (Ecourt-The Online Justice System, 2021b). Finally, it is essential to mention that the e-arbitral award is not binding and final unless otherwise agreed by the parties (Ecourt-The Online Justice System, 2021c).

Regarding the key advantages of e-arbitration, the e-arbitral proceedings in earbitration would be conducted and administered in a single web-based user platform. Therefore, e-arbitration would enable parties and arbitral members to remotely and onsite conduct paperless arbitral proceedings. This would decrease the cost and time of printing and distributing the legal documents. Furthermore, hearings in e-arbitration would be made with fully built-in digital means designated for the preparation, transcription, and presentation of legal arguments and evidence. This, in turn, alleviates the logistical complications of the hearing process and speeds up the process of resolution in Islamic banking disputes, especially for those located at a distance because remote communication obviates the need for travel.

\section{Conclusion}

This article strived to critically and analytically examine the regulatory framework governing traditional arbitration in resolving Islamic banking disputes in Malaysia. It is found that Islamic banking disputes can be resolved by using Arbitration Act 2005 (Act 646) or I-Arbitration Rules 2018.

Regarding the development of the ad hoc arbitration system, it is clear that Malaysian lawmakers have made considerable efforts to ensure that Arbitration Act 2005 (Act 646) aligns with the best practices and international norms. Specifically, Arbitration Act 2005 (Act 646) has passed seven phases. The latest phase brought the Arbitration Act 2005 (Act 646) in line with the MLICA 1985 as amended in 2006. It also addressed certain deficiencies identified in Arbitration Act 2005 (Act 646) and brought new amendments. For instance, it reduced the court intervention in the traditional arbitral proceedings (section 8), provided legal recognition to the arbitral agreement that is made by using ICT (section 9), ensured confidentiality of the traditional arbitral proceedings (sections $41 \mathrm{~A}$ and $41 \mathrm{~B}$ ), and excluded the right of a party to refer to the Malaysian High Court on any questions of law arising from an award by removing sections 42 and 43.

Concerning the development of the institutional arbitration system, it is discovered that AIAC provides a unique legal instrument. This legal instrument is not available in other arbitration centers, such as the International Court of Arbitration (ICA) and Permanent Court of Arbitration (PCA), and it is designed to resolve disputes arising from commercial contracts containing Shariah issues. One of its unique advantages is seen under rule 11 that outlines the procedure for referral a Shariah matter included in an arbitration dispute to Shariah expert or SAC. 
Regardless of the above, it is found that traditional arbitration is not generally considered an efficient and effective remedy for resolving the Islamic banking disputes in Malaysia. It is expensive and time-consuming. On the other hand, several jurisdictions, such as China, Thailand, Russia, and the United States of America (USA), have developed their arbitration laws towards integrating ICT in the process of dispute resolution. Specifically, they implemented e-arbitration, unlike Malaysia.

Hence, it is recommended that the Malaysian arbitration industry has to move a step forward and modernize its arbitration services. This can be achieved by adopting and implementing e-arbitration that can provide fast and cheap resolution. Doing so would take the arbitration industry in Malaysia to the next level, and Kuala Lumpur would also become a global hub for resolving Islamic banking disputes.

\section{Acknowledgment}

The authors would like to thank Perpustakaan Sultanah Bahiyyah, Universiti Utara Malaysia for the resources provided to conduct this research. Sincere gratitude also goes to anonymous reviewers and editors who have provided constructive feedback so that this manuscript looks worth reading and citing.

\section{Declarations}

Author contribution : Author 1: Initiated the idea; conducted a literature review; prepared research methodology; data collection and analysis; writing draft. Author 2: Revise the research idea; revised research methodology; revised the analysis; revised final draft. Author 3: Revised analysis; revised language; revised presentation of final draft.

Funding statement $\quad$ : This research is not funded under any research project.

Conflict of interest : The authors declare no conflict of interest.

Additional information : No additional information is available for this paper.

\section{References}

Al-shibli, F. S. (2017). the Role of Arbitration in Settling the Dispute of Islamic Banking. Journal of Humanities, Language, Culture and Business, 1(2), 221-229.

Al-Shibli, F. S. (2018). Litigation or Arbitration for Resolving Islamic Banking Disputes. Arab Law Quarterly, 32(4), 413-438. https://doi.org/10.1163/15730255-12324040

Al Hamed, M. (2016). Electronic arbitration as A Solution for Electronic Commerce Dispute Resolution in the United Arab Emirates: Obstacles and Enforceability Challenges. University of Gloucestershire.

Ali, E. R. A. E., Oseni, U. A., Adeyemi, A. A., \& Mohd. Zein, N. R. (2016). Disputre Resolution Mechanism in the Islamic Finance Industry in Malaysia: Towards a Legal Framework. Al-Shajarah: Journal of Islamic Thought and Civilization of the International Islamic University Malaysia (ISTAC), 43(Special Issue), 19-40.

Ali, S., Mohamed Yusoff, Z., \& Ayub, Z. (2017). Legal Research of Doctrinal and Non- 
Doctrinal. International Journal of Trend in Research and Development, 4(1), 493495.

Allie, S. (2020). Exploring the concept of conciliation (șulh) as a method of alternative dispute resolution in Islamic Law. University of Western Cape.

Arifin, M., \& Mansar, A. (2019). Features of arbitration in Islamic law when resolving disputes in muamalah. International Journal of Innovation, Creativity and Change, 9(10), 295-311.

Asian International Arbitration Centre. (2018). The Arbitration (Amendment) (No. 2) Act 2018 Comes Into Force - The New Era of Arbitration in Malaysia.

Asian International Arbitration Centre. (2020). Virtual Reality Unlocking Potentials for $A D R$.

Asian International Arbitration Centre. (2021). I Arbitration Rules. Asian International Arbitration Centre.

Bello, A. T. (2018). Online Dispute Resolution Algorithm: The Artificial Intelligence Model as a Pinnacle. Arbitration: The International Journal of Arbitration, Mediation and Dispute Management, 84(2), 159-168.

Born, G. B. (2009). International Commercial Arbitration (1st ed.). Kluwer Law Inernational.

Born, G. B. (2010). International Arbitration and Forum Selection Agreements: Drafting and Enforcing (3rd ed.). Kluwer Law Inernational.

Dahlan, N. K. (2018). Alternative Dispute Resolution for Islamic Finance in Malaysia. MATEC Web of Conferences, 150, 11-20. https://doi.org/10.1051/matecconf/201815005077

Ecourt-The Online Justice System. (2021a). How it Works.

Ecourt-The Online Justice System. (2021b). How Long Does it Take.

Ecourt-The Online Justice System. (2021c). The Legality of the Rulings.

Ecourt-The Online Justice System. (2021d). Who Can Use It.

Fortese, F., \& Hemmi, L. (2015). Procedural Fairness and Efficiency in International Arbitration. Groningen Journal of International Law, 3(1), 110. https://doi.org/10.21827/5a86a89d8e651

Hua, T. C. (2018). Challenges against arbitral awards in Malaysia. Universiti Teknologi Malaysia.

Husseini, S. A., Fam, S. F., Ahmat, N. N., Azmi, F. R., Prastyo, D. D., \& Yanto, H. (2019). Islamic banking revolution in Malaysia: A review. Humanities and Social Sciences Reviews, 7(4), 267-275. https://doi.org/10.18510/hssr.2019.7434

Idid, D. S. A., \& Oseni, U. A. (2014). the Arbitration (Amendment) Act 2011: Limiting Court Intervention in Arbitral. The Malayan Law Journal, 2, 1-21.

Khakimov, S. (2020). Arbitration (Tahkim) and Reconciliation (Sulh) in Islam As Alternative Dispute Resolution Mechanisms. The Light of Islam, 2020(4), 31-37. https://doi.org/10.47980/tloi/2020/4/20

Khoukaz, G. (2017). Sharia Law and International Commercial Arbitration: The Need for an Intra-Islamic Arbitral Institution. Journal of Dispute Resolution, 2017(1), 1-17. 
Komijani, A., \& Taghizadeh-Hesary, F. (2018). An overview of Islamic banking and finance in Asia. In ADBI Working Paper Series (No. 853). https://doi.org/10.4324/9781315543222-28

Labanieh, M. F., Hussain, M. A., \& Mahdzir, N. (2019). Arbitration as a Mechanism to Resolve Islamic Banking Dispute in Malaysia: Challenges and Drawbacks. UUM Journal of Legal Studies, 10(2), 19-44.

Labanieh, M. F., Hussain, M. A., \& Mahdzir, N. (2020). E-Arbitration: A way forward to improve quality and service delivery in Malaysian dispute resolution industry. International Journal of Supply Chain Management, 9(3), 136-141.

Labanieh, M. F., Hussain, M. A., \& Mahdzir, N. (2021). Does E-Arbitration Provide a Suitable Response for the "New Normal" Phenomenon During the Era of Covid19 Pandemic? International Journal of Law, Government and Communication, 6(22), 215-226. https://doi.org/10.35631/ijlgc.6220021

Link, M., \& Haftel, Y. Z. (2019). Islamic legal tradition and the choice of investment arbitration forums. Review of International Political Economy, 28(3), 1-25. https://doi.org/10.1080/09692290.2019.1679223

Mahdi, Z., \& Hak, N. A. (2006). Tahkīm (Arbitration ) in Islamic Law within the Context of Family Disputes. Arab Law Quarterly, 20(1), 2-42.

Maita, A. (2014). Arbitration of Islamic Financial Disputes. Annual Survey of International \& Comparative Law, 20(1), 35-71.

Mohamed, A. M. T., Makhtar, M., Hamid, N. A., \& Asari, K. N. (2015). Arbitration as a method of dispute settlement in Islamic banking and finance: A perspective from Malaysian governing law. Pertanika Journal of Social Sciences and Humanities, 23(Special Issue 11), 153-164.

Mohamed, K. (2016). Combining Methods in Legal Research. The Social Science, 11(21).

Oseni, U. A., \& Ahmad, A. U. F. (2012). Blazing the Trail : The Institutional Framework for Dispute Resolution in Malaysia's Islamic Finance Industry. ISRA International Journal of Islamic Finance, 4(2), 159-165. https://doi.org/10.12816/0002753

Peter Berger, K. (2018). Institutional arbitration: harmony, disharmony and the 'Party Autonomy Paradox.' Arbitration International, 34(4), 473-493. https://doi.org/10.1093/arbint/aiy028

Pradhan, A. (2018). Malaysia. In J. H. Carter (Ed.), International Arbitration Review (9th ed.). Law Business Research Ltd.

Rajoo, S. (2009). Law, Practice and Procedure of Arbitration-The Arbitration Act 2005 Perspective. Malayan Law Journal, 2(February), 136-161.

Rajoo, S. (2010). Institutional and Ad hoc Arbitrations: Advantages and Disadvantages. The Law Review, 547-558.

Rajoo, S. (2019). Arbitration in Malaysia. Arbitration Journal, 5, 23-33.

Rajoo, S., \& Choy, C. Y. (2018). Malaysia. In G. F. Bell (Ed.), The UNCITRAL Model Law and Asian Arbitration Laws Implementation and Comparisons. Cambridge University Press.

Rosli, I. C. (2021). International commercial arbitration in malaysia. 
Pertanika Journal of Social Sciences and Humanities, 29(2), 135-148. https://doi.org/10.47836/pjssh.29.s2.10

Schroeter, U. G. (2018). Ad Hoc or Institutional Arbitration - A Clear-Cut Distinction? Contemporary Asia Arbitration Journal, 10(2), 141-199. https://doi.org/10.2139/ssrn.3086537

Seyadi, R. M. (2019). Intellectual Composition of Arbitral Tribunals According to the New Saudi Arbitration Law. Arab Law Quarterly, 33(1), 99-108. https://doi.org/10.1163/15730255-12331028

Shokrani, M. (2018). Institutional arbitration versus ad hoc arbitration: Chinese and Iranian perspectives. Journal of Advanced Research in Social Sciences and Humanities, 3(4), 148-154. https://doi.org/10.26500/jarssh-03-2018-0404

Strong, S. I. (2012). Does Class Arbitration "Change the Nature" of Arbitration? StoltNielsen, AT\&T, and a Return to First Principles. Harvard Negotiation Law Review, 17(Spring), 201-272.

Yaqin, A. (2007). Legal Research and Writing. Lexis Nexis. 